\title{
Regulation of the state debt stability
}

Maksym Antonov

Ph.D., Sumy State University, Ukraine

\section{Liliana Lopa}

\author{
Ph.D. Student, Sumy State University, Ukraine
}

\begin{abstract}
The purpose of the study is the improvement of theoretical ideas, scientific and methodological approaches to managing debt sustainability of the state and its assessment. The purpose in view caused the necessity to solve the following tasks: to carry out a decomposition analysis of the essence of the concept "debt sustainability" and identify its key determinants; to systematize the global and domestic experience of managing debt sustainability; to develop a risk-based approach to assessing debt sustainability indicators; to examine the impact of macroeconomic and financial factors on the debt sustainability of the world and Ukraine; to develop a scientific and methodological approach to identifying debt crises; to devise a structural and logical scheme for the functioning of an independent fiscal institution (IFI) in Ukraine; to improve the organizational and economic support for the implementation of fiscal (debt) rules in Ukraine; to elaborate a theoretical and methodological framework for auditing the effectiveness of the public debt. The scientific novelty of findings improved the following: scientific and methodological risk-oriented approach to the construction of an integrated indexed system for assessing the debt sustainability of the state, which provides the calculation of indices of debt sustainability in countries with different levels of income per capita at the first level and at the second level - the assessment of Ukrainian debt sustainability in terms of solvency, liquidity and vulnerability, which, unlike the existing ones, combines both static and dynamic approaches to analyzing the level of debt sustainability and allows early signaling of the risks of its loss. Methodological rationale for determining the influence of exogenous factors on the debt sustainability of the state on the basis of a system of multifactorial regression models that, unlike existing ones, consider a set of macroeconomic factors (demography and labor market, real sector, balance of payments) and financial nature (capital flows, monetary market, banking system and access to financing), and allow for a comprehensive assessment of the mechanism of mutual combination of such factors in the effects of debt spirals: "double deficit of the balance of payments is a deficit in the state budget", "international reserves - devaluation-inflationary spiral", "inflation - fall in industrial production and GDP".
\end{abstract}

Keywords: debt stability, international reserves, inflation, debt sustainability, fiscal institution.

JEL Classification: E62, H60, H63.

\section{Introduction}

Unprecedented increase in the volume of public debt by 25 trillion in 2014 compared to 2007 primarily in developed countries of the world strengthens the prerequisites to the emergence of full-blown debt crises. Significant efforts of the European countries aimed at overcoming the insolvency crisis in Greece and other countries of the PIGS group are speaking volumes for the need to revise the principles and methods of public debt management and debt sustainability of the EU member states. Fiscal consolidation, the limitation of the expansive debt policy by the real ability of the economy to reproduce and growth, leveling the impact of macroeconomic shocks and risks become today as key issues while achieving debt sustainability.

The agreement on restructuring public debt of Ukraine concluded in the autumn of 2015 can be considered as a case of technical default on sovereign obligations, actualizing the need to revise approaches to managing debt sustainability and public debt at the national level, considering the complex military and political and economic situation that determine the imbalances in the field of finance interests in general and the debt sphere, in particular.

Theoretical and methodological approaches to managing debt stability were laid in the works of foreign and domestic scientists, in particular B. Alekhin, R. Barro, O. Blanchard, T. Bogdan, L. Braginska, V. Vavylov, T. Vakhnenko, A.R. Ghosh, O. Grublyak, X. Debrun, N. Zrazhevska, V. Kalytchuk, L. Calmfors, O. Karapetyan, J.M. Keynes, T. Kinda, V. Koziuk, A. Kolot, M. Kumar, G. Kucher, O. Londar, S. Londar, R.A. Musgrave, R. Neck, J.-E. Sturm, I. Fedorovych, V. Fedosov, R. Tsytsyk and others.

At the same time, a critical analysis of scientific sources on the chosen topics confirms that at present a number of theoretical and methodological issues concerning, in particular the definition of the essence of the concept of "debt sustainability", ordering the tools for assessing its level and identifying debt crises, formalization of 
factors influencing debt sustainability, improvement of institutional and instrumental support for debt sustainability management, use of audit of public debt efficiency as a basis for increasing the transparency of the state debt sustainability management system has not been sufficiently solved. Insufficient solution of indicated problems and the need to form a holistic approach to the implementation of debt management of the state in conditions of fiscal imbalances determined the relevance of the study, its purpose, objectives and content.

Purpose and objectives of the study. The purpose of the study is the improvement of theoretical ideas and scientific and methodological approaches to managing debt sustainability of the state and its assessment.

The purpose in view caused the necessity to solve the following tasks:

$>$ to carry out a decomposition analysis of the essence of the concept "debt sustainability" and determine its key determinants;

$>$ to systematize the global and domestic experience of managing debt sustainability;

$>$ to develop a risk-based approach to assessing debt sustainability indicators;

$>$ to examine the impact of macroeconomic and financial factors on the debt sustainability of the world and Ukraine;

$>$ to develop a scientific and methodological approach to identifying debt crises;

$>$ to devise a structural and logical scheme for the functioning of an independent fiscal institution (IFI) in Ukraine;

$>$ to improve the organizational and economic support for the implementation of fiscal (debt) rules in Ukraine;

$>$ to elaborate a theoretical and methodological framework for auditing the effectiveness of the public debt.

The subject of the study is the system of public debt management and debt sustainability.

The study object is economic relations arising between government institutions, international financial organizations, local authorities regarding the formation, use and repayment of debt obligations.

\section{Methodology}

The methodology of the study is based on economic theory, the theory of finance, management theory, and scientific achievements of foreign and domestic researchers on issues of debt sustainability management.

In accordance with above tasks, the following methods of scientific research were used: decomposition analysis - to determine the essence and formalization of the concept "debt sustainability"; logical generalization and scientific abstraction, comparative analysis - to systematize the world and domestic practice of debt sustainability management, identification of its determinants, rationale for categorical apparatus; methods of statistical analysis - for assessing indicators of debt sustainability and forecasting debt crises; correlation analysis - to assess the impact of factors on the level of debt sustainability.

The information-factual base of the research is the legislation of Ukraine, the report and analytical information of the Ministry of Finance of Ukraine, the State Statistics Service of Ukraine; regulatory and reporting documents of the Organization for Economic Cooperation and Development, the European Commission, the International Monetary Fund, analytical data of the World Bank; results of research on issues of public debt management and debt sustainability.

The scientific novelty of findings of the study is in the development of theoretical and scientific and methodological provisions as to the elaboration of the assessment instrument and managing debt sustainability of the state. The scientific novelty of findings improved the following:

$>$ Scientific and methodological risk-oriented approach to the construction of an integrated indexed system for assessing the debt sustainability of the state, which provides the calculation of indices of debt sustainability in countries with different levels of income per capita at the first level and at the second level - the assessment of Ukrainian debt sustainability in terms of solvency, liquidity and vulnerability, which, unlike the existing ones, combines both static and dynamic approaches to analyzing the level of debt sustainability and allows early signaling of the risks of its loss.

$>$ Methodological rationale for determining the influence of exogenous factors on the debt sustainability of the state on the basis of a system of multifactorial regression models that, unlike existing ones, take into account a set of macroeconomic factors (demography and labor market, real sector, balance of payments) 
and financial nature (capital flows, monetary market, banking system and access to financing), and allow for a comprehensive assessment of the mechanism of mutual combination of such factors in the effects of debt spirals: "double deficit of the balance of payments is a deficit in the state budget", "international reserves - devaluation-inflationary spiral", "inflation - fall in industrial production and GDP".

> Scientific and methodological approach to the assessment of debt sustainability of Ukraine, in such sequence: integral, elemental evaluation using Shewhart cards and revealing the anomalous (crisis) values of certain debt indicators (general government sector, central bank, depository corporations (except for the central bank) and other sectors (corporate) based on their verification by the Irvine method. It allows us to fix the ranges of loss of debt sustainability - the emergence of debt crises both at annual and quarterly periods and focused on their early forecasting.

$>$ A theoretical approach to defining the essence of an "independent fiscal institution" as a public institution with a status, mission and objectives determined at the normative level, parity participation with executive and legislative authorities in formation, implementation, evaluation of efficiency and optimization of the government's debt sustainability policy, in particular and fiscal policy in general, characterized by political isolation (nonpartisanship), security of funding and public accountability. In contrast to the existing ones, it makes it possible to clearly identify the IFI as a generic concept, to determine their status and role in managing the debt sustainability of the state and develop a structural and logical scheme for their functioning.

$>$ A structural and logical scheme for the operation of the IFI in Ukraine, which provides for: (1) the delineation of the functions and tasks of the institution's triad - again the institutions, the Ministry of Finance and the National Bank of Ukraine agreed with financial, monetary and fiscal policies, their strategic orientations and tactical means of achieving them within the Coordination Council; (2) the dichotomy of priorities in the activities of the IFI for analyzing long-term fiscal sustainability, ensuring social efficiency, intergenerational equity equality, transparency of debt management, and establishing effective fiscal targets at strategic and tactical levels; 3) distribution of tasks on the basis of the code of ethics within the agency in three directions: front, middle and back-office. Unlike the existing ones, the developed scheme is based on Recommendations on principles for independent fiscal institutions of the OECD and the IMF's Public Debt Management Guide and takes fully into account the features of the US debt management model.

Instrumental support of debt sustainability management of the state is the introduction of debt targets and rules.

Improving the architecture of fiscal (fiscal) rules is a key trend in reforming approaches to managing the fiscal sustainability of the world. The transition to the rules of the "second generation", which are flexible and counter-cyclical in many countries, is an integral part of anti-crisis measures. Particular importance of these measures in the light of the need for fiscal consolidation is acquired in countries with a high level of sovereign debts in general and in the EU countries in particular, with heterogeneous economic and institutional structures, but which are striving for the formation of a fiscal union.

With the introduction of fiscal reform in March 2012, the adoption of the Fiscal compact of the EU (the Treaty on Stability, Coordination and Regulation in the Economic and Monetary Union), since 2014 a number of existing fiscal rules in the community has been modified.

In particular, the following updated fiscal rules have been established for member countries: mandatory targeting of cyclically adjusted budget balance at $0.5 \%$ of GDP and $1 \%$ for countries with a public debt quota up to $60 \%$ (a balanced budget rule) GDP by not less than 5\% of the deviation between the actual and the debt limit in 3 years after overcoming the excessive budget deficit to 3\% of GDP (debt rule), targeting the growth rates of public spending that should not be larger than rates of long-term GDP growth (the expenditure rule).

If Ukraine gains the status of an associate member of the EU, it will focus on its implementation of the standards of debt sustainability, fiscal discipline and fiscal consolidation, which poses new challenges to the public debt management system in general, and requirements for implementing effective fiscal rules.

The specifics of the use of one or another type of fiscal rules are disclosed through their advantages and disadvantages (Table 1). Thus, in general, the implementation of the mechanism of fiscal rules in the system of governance of the state's debt sustainability is based on a number of arguments "for" concerning the strengthening of government responsibility and regularity and timeliness in making decisions on the implementation of state borrowings, the formalization of the response to certain fiscal shocks, the promotion of a transparent and more balanced budget process and fiscal policy. At the same time, the application of fiscal rules encounters a series of restrictions on the short-term horizon of rules that do not solve the problem of 
long-term debts for an expansive policy of increasing the low effectiveness of rules in the case of poor quality of the institutional framework for managing public debt and debt sustainability.

Having analyzed the advantages and disadvantages of introducing specific types of rules, it is necessary to note the absence of a panacea rule from all problems in the field of debt sustainability management: considering the cyclical nature of the economy, the budget balance rules (structural, cyclical) are quite difficult to implement, although they have a pronounced anticyclical effect. The rules of income and expenditure should have a better effect in case of their joint application. Despite the ease of implementation and interpretation of debt rules, their pronounced procyclicality does not allow using them to eliminate the procyclicality of fiscal policy.

Table 1. Features of fiscal (debt) rules application

\begin{tabular}{|c|c|c|c|c|}
\hline \multirow[b]{2}{*}{ Description } & \multicolumn{4}{|c|}{ Type of rule } \\
\hline & DR & $\begin{array}{l}\text { BBR, including the rule of } \\
\text { structural and cyclical balance }\end{array}$ & ER & RR \\
\hline \multirow{3}{*}{ 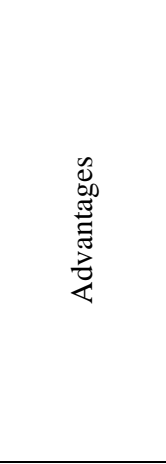 } & $\begin{array}{l}\text { A simple mechanism of } \\
\text { establishment and } \\
\text { implementation, } \\
\text { understandable to economic } \\
\text { agents, contributes to the } \\
\text { predictability of fiscal } \\
\text { policy. }\end{array}$ & $\begin{array}{l}\text { The basis for fiscal } \\
\text { consolidation with close } \\
\text { linkage to the business cycle } \\
\text { stages. }\end{array}$ & \multicolumn{2}{|c|}{$\begin{array}{l}\text { Close connection with the public debt in their } \\
\text { joint application. }\end{array}$} \\
\hline & \multirow{2}{*}{$\begin{array}{l}\text { Easily yields to monitoring, } \\
\text { control and audit } \\
\text { effectiveness. }\end{array}$} & $\begin{array}{l}\text { It fully takes into account all } \\
\text { the changes that affect the } \\
\text { dynamics of GDP and debt, } \\
\text { considering their cyclical nature }\end{array}$ & \multicolumn{2}{|c|}{$\begin{array}{l}\text { Easily yields to monitoring, control and audit } \\
\text { effectiveness. }\end{array}$} \\
\hline & & \multicolumn{3}{|c|}{$\begin{array}{l}\text { Provide clear guidelines for corrective actions with regard to fiscal policy and } \\
\text { debt management. }\end{array}$} \\
\hline \multirow{3}{*}{ 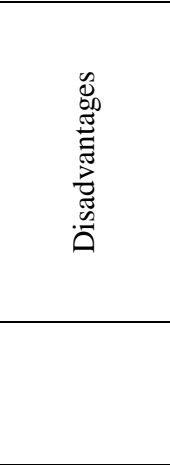 } & $\begin{array}{l}\text { It is a rule-statement and } \\
\text { does not contain a guide to } \\
\text { action. }\end{array}$ & $\begin{array}{l}\text { Complex rule for monitoring, } \\
\text { control and audit effectiveness. }\end{array}$ & \multicolumn{2}{|c|}{$\begin{array}{l}\text { Establishes restrictions for the general national } \\
\text { (government) sector and incentives for circum- } \\
\text { vention. }\end{array}$} \\
\hline & $\begin{array}{l}\text { It can serve as a basis for } \\
\text { manipulating transactions } \\
\text { with conditional } \\
\text { government obligations. }\end{array}$ & $\begin{array}{l}\text { It should be accompanied by a } \\
\text { qualitative basis for planning } \\
\text { and forecasting budget aggre- } \\
\text { gates to identify potential im- } \\
\text { pacts of cyclical shocks. }\end{array}$ & $\begin{array}{l}\text { Effective use in } \\
\text { managing debt } \\
\text { sustainability only } \\
\text { in combination } \\
\text { with the revenue } \\
\text { rule. }\end{array}$ & $\begin{array}{l}\text { Effective use in } \\
\text { managing debt } \\
\text { sustainability only in } \\
\text { combination with ex- } \\
\text { penditure rule. }\end{array}$ \\
\hline & $\begin{array}{l}\text { The time lag in the applica- } \\
\text { tion of the rule does not give } \\
\text { a short-term effect. }\end{array}$ & $\begin{array}{l}\text { The need for highly qualified } \\
\text { specialists in managing } \\
\text { sustainability and applying the } \\
\text { rule. }\end{array}$ & & \\
\hline $\begin{array}{l}\text { Countries of } \\
\text { the world }\end{array}$ & 66 & 52 & 26 & 5 \\
\hline
\end{tabular}

Source: compiled and added by authors [according to 6,8$]$.

The establishment of a rule should consider the objectives of fiscal policy on all time horizons, taking into account their advantages and disadvantages. In some countries of the world and their associations, fiscal rules as the basis for fiscal convergence is an integral part of the convergence criteria aimed at the closest coordination of not only monetary or economic but also fiscal policies in order to overcome the heterogeneity of the countries of integration and their macroeconomic stabilization (Table 2).

Table 2. Implementation of fiscal convergence criteria (regulations) by monetary unions

\begin{tabular}{|c|c|c|}
\hline Union & Type of rule & Targets \\
\hline $\begin{array}{l}\text { The Eastern Caribbean } \\
\text { Currency Union }\end{array}$ & Debt & The level of public debt should be below $60 \%$ of GDP by 2020 . \\
\hline \multirow{2}{*}{ The European Union } & Balance & The level of the budget deficit is not more than $3 \%$ of GDP. \\
\hline & Debt & The level of public debt should be below $60 \%$ of GDP. \\
\hline \multirow{2}{*}{$\begin{array}{l}\text { The West African Economic } \\
\text { and Monetary Union }\end{array}$} & Debt & The level of public debt should be below 70\% of GDP. \\
\hline & Balance & Support for a balanced budget. \\
\hline \multirow[t]{2}{*}{$\begin{array}{l}\text { The Economic and Mone- } \\
\text { tary Community of Central } \\
\text { Africa }\end{array}$} & Debt & The level of public debt should be below $70 \%$ of GDP. \\
\hline & Balance & $\begin{array}{l}\text { Support for a balanced budget, subject to exclusion from international grants } \\
\text { and assistance. }\end{array}$ \\
\hline
\end{tabular}

Source: [2]. 
The the best known fiscal rules that simultaneously act as fiscal convergence criteria are the EU rules (Maastricht Criteria for Convergence (1992), the Stability and Development Pact (1997), the Sixpack and the Stability, Coordination and Governance Agreement (2012-2014).

Beyond monetary and economic unions, fiscal rules have also become widespread: most of the countries of the world considered in the database on fiscal rules of the IMF operate with 2 rules -49 countries.

Only six countries use all types of fiscal rules discussed above (Figure 1): Australia, Belgium, Denmark, Lithuania, France, the Netherlands.

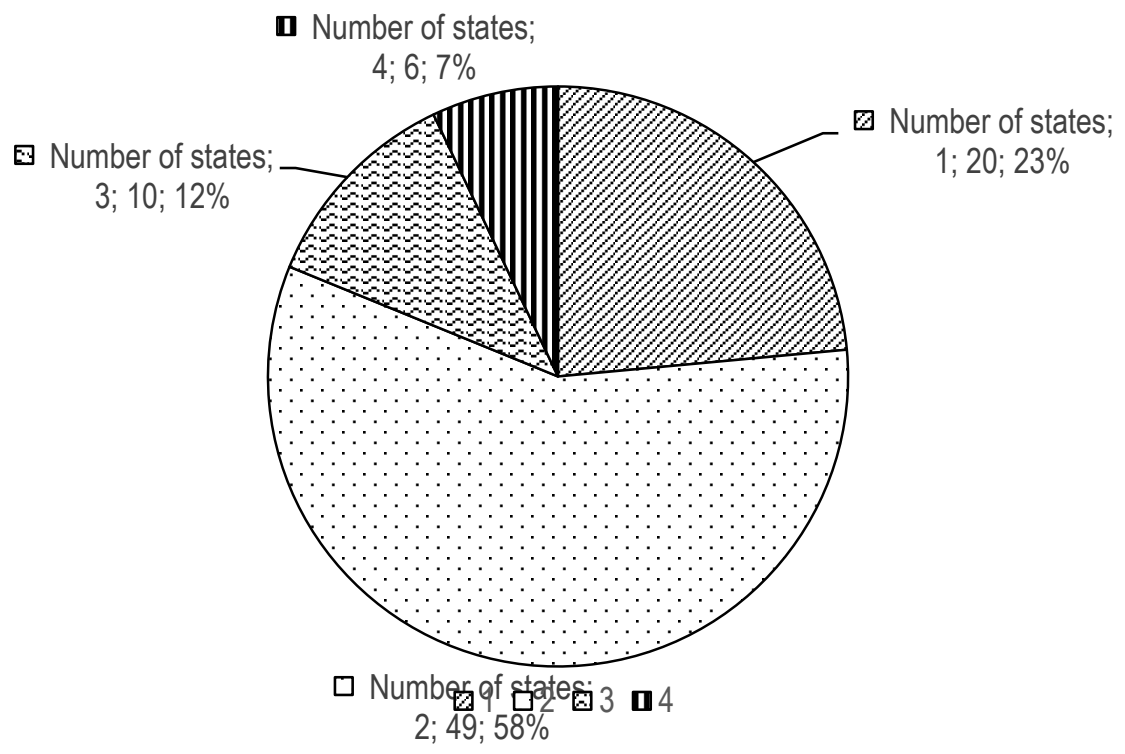

Figure 1. Number of fiscal rules in the world

Source: compiled by authors [4].

The regulation of the implementation of these rules is achieved both at the level of national legislation and at the level of supranational obligations accepted by the countries of the world, including in the framework of associations (Figure 2).

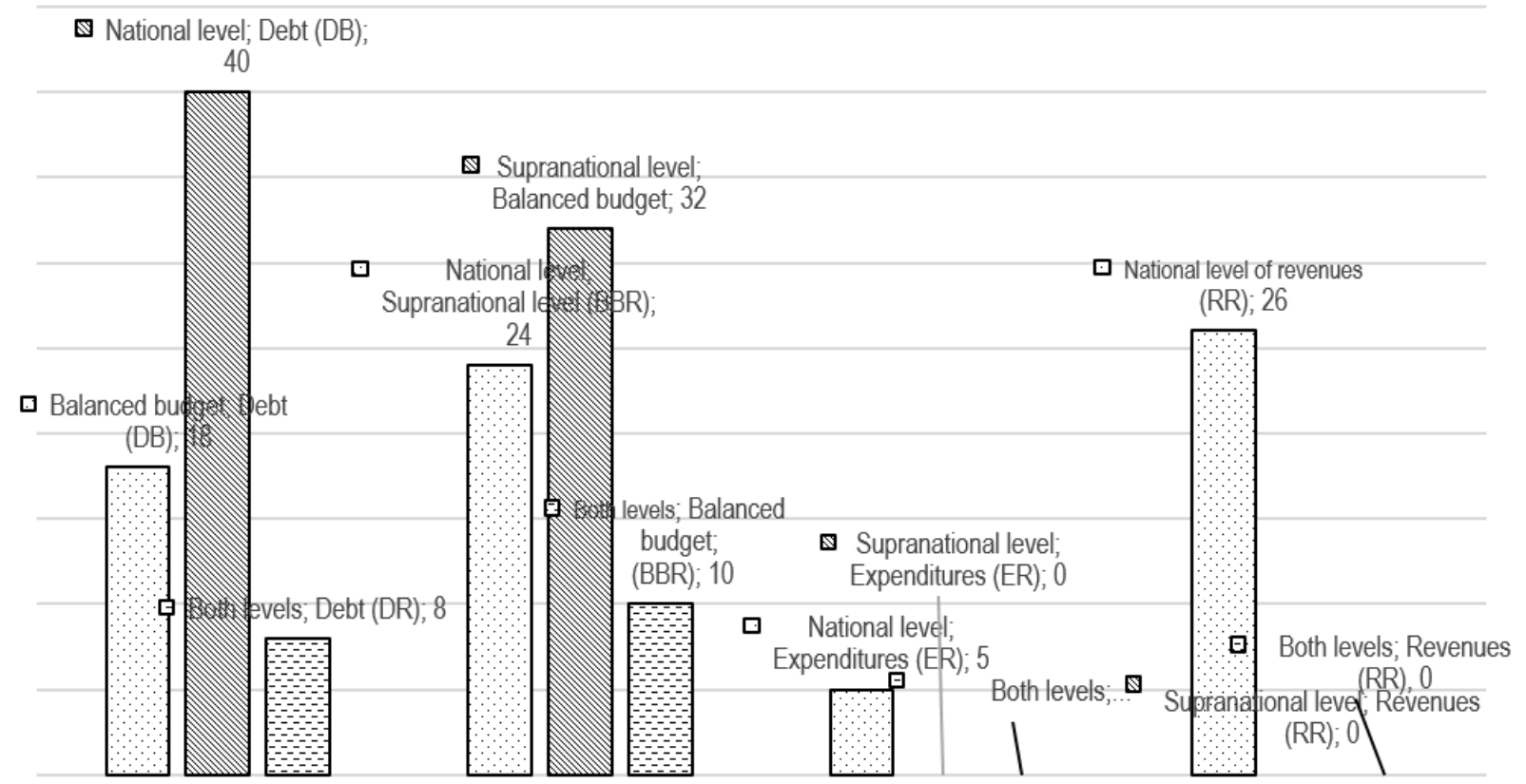

Figure 2. Regulation of fiscal rules in countries of the world

Source: compiled by authors [4]. 
The scope and mechanisms for ensuring their implementation (responsibility) are important aspects that characterize the world experience of introducing fiscal rules, in addition to their species diversity and regulation.

The key trend in the distribution of fiscal rules to the levels of public finances in the world is the transition to covering not only the level of central government - the state budget, but also the entire public finances, including local budgets, state trust funds, state company and bank finances. The ratio of countries applying a broad and narrow approach today is 50 to 50, and among the countries belonging to a broader approach are the EU, Argentina, Austria, Brazil, Georgia, Indonesia, Hong Kong, Panama, Russia and the United Kingdom.

Mechanisms ensuring the implementation of fiscal rules are very important primarily for countries that have facts of fiscal rules violation. These include countries with poor fiscal discipline. More than 30 countries with fiscal rules have already introduced similar enforcement mechanisms to execution of rules. Among them one can also name the laws on fiscal responsibility, which establishes the responsibility of the government to the parliament for compliance with proper rules, and supervision of compliance with the IFI rules discussed above, and supervision of compliance with the rules of supranational institutions (ECOFIN).

The consideration of the world experience in the application of fiscal rules should be supplemented by an analysis of the limitations for fiscal policy and their role in managing debt sustainability in Ukraine. In conditions of considerable discreteness, characterizing the system of public debt management, debt sustainability and Ukraine's fiscal policy, the low level of development of automatic stabilizers, the architecture of fiscal rules and the state of their compliance are rather debatable. This fact is indicated by T. Savchenko [3], R. Tsytsyk $[7,8]$.

Analyzing the state of implementation and execution of fiscal rules in Ukraine, it should be noted that they are at the stage of their formation: there are separate norms of budget legislation that have a restrictive impact on the amount of public debt, but the state of implementation and compliance mechanisms are insufficient.

National legislation contains the initial elements of the architecture of such fiscal (debt) rules as debt rules, the rules of the budget balance, the rules of income (reserves).

Thus, Articles 16 and 18 of the Budget Code of Ukraine refer to the fact that public debts are carried out within the limits determined by the Law on the State Budget of Ukraine, with observance of the limit of the state debt (including the guaranteed one), which at the end of the budget period cannot exceed $60 \%$ of annual nominal volume of Ukraine's GDP and $200 \%$ for local debt (for Kiev-400\%) of the average annual indicative forecasted amount of development budget revenues.

It should be noted from European practice that the debt of the $60 \%$ threshold of the public debt quota in GDP, is incompatible with the realities of the Ukrainian economy, the debt sustainability limit of which is developing according to the methodology of the IMF, and is much lower, or with the full account of this debt indicator of off-budget funds, local communities and state companies and banks.

Per the rule of balance of the budget, its legislative consolidation is implemented by Article 95 of the Constitution of Ukraine, which indicates that the state seeks to balance the budget of Ukraine. At the same time, in the interpretations of this norm and in separate laws of Ukraine "On the State Budget" for the relevant year, which set the maximum deficit to GDP (usually not more than 3\%), only the state budget is noted and the aggregate of deficit trust funds (including the Pension Fund) and subsidized companies (Naftogaz) and territorial communities (budgets of individual cities) is left without attention, which has a twisted effect on the total amount of public debt. The fact that the 3\% deficit is approaching the Maastricht Criteria of the EU is completely leveled by recording of receipts, expenses and debt-collection operations in Ukraine by the cash method rather than the accrual method, and, as it was already noted, by calculating this indicator against the state budget, and not of the entire sector of general government. In addition, the principles laid down as the basis for the equality of revenues and expenditures of the budget, in particular pay-as-you-go (PAYGO), the sequester of budget expenditures, the availability of well-founded sources of budget financing to cover its deficit and the prohibition of emission financing of the National Bank of Ukraine deficit (taking into account the redemption of government securities of the National Bank of Ukraine or state-owned banks).

The use of reserve fund, the creation of which is provided for in Article 24 of the Budget Code of Ukraine in the amount of $1 \%$ of the total budget of the corresponding budget for the implementation of unforeseen ex- 
penses, which are not of a permanent nature and could not be provided for in drafting the budget, unfortunately, does not have any signs of a fiscal rule. Directions of additional amounts of income with a surplus budget to the reserve fund in Ukraine are not provided, and its role in macroeconomic stabilization and smoothing of cyclical fluctuations is not established.

A single role as quasi-fiscal rule is claimed by the commitments undertaken by Ukraine in the course of implementation of the Memorandum of Economic and Financial Policies concluded with the IMF in 2015. Among the general course for ensuring the sustainability of public debt, fiscal consolidation in the mid-term, the key interim targets for 2018-2020 are the reduction of the state debt quota in GDP to 71\%, the combined deficit of the general government and Naftogaz to $2.6 \%$, the construction of a primary balance of the budget with a surplus of $1.6 \%$. At the same time these obligations are only the basis for the introduction of a fullfledged system of fiscal rules and a model of fiscal policy.

Despite a low institutional quality and effectiveness of the limitations discussed in the debt sphere of Ukraine, it is necessary to pay attention to one more important point characterizing their target orientation.

One of the key tasks of the fiscal rules considered at the beginning is to reduce the procyclical nature of fiscal policy, and equalize it within the business cycle. Each rule affects the procyclicality of fiscal policy of uneven degree (Figure 3).

\begin{tabular}{|c|c|c|c|}
\hline DR & $\begin{array}{l}\text { BBR (Structural and cyclical } \\
\text { balance) }\end{array}$ & ER & $\mathrm{RR}$ \\
\hline $\begin{array}{l}\text { Significant procyclicality, } \\
\text { given that fiscal consolidation } \\
\text { may be needed in the recession } \\
\text { stage. }\end{array}$ & $\begin{array}{l}\text { Expressed countercyclical ef- } \\
\text { fect given the allocation of the } \\
\text { cyclic component for budget } \\
\text { balancing. }\end{array}$ & $\begin{array}{l}\text { Expressed countercyclical } \\
\text { effect given the direct impact } \\
\text { on aggregate demand through } \\
\text { public expenditures. }\end{array}$ & $\begin{array}{l}\text { Significant procyclicality, ex- } \\
\text { cept in cases of a clear regula- } \\
\text { tion of the use of cyclical in- } \\
\text { come. }\end{array}$ \\
\hline $\begin{array}{l}\text { The impact on debt } \\
\text { sustainability and } \\
\text { macroeconomic stabilization is } \\
\text { negligible. }\end{array}$ & $\begin{array}{l}\text { Significant impact on debt } \\
\text { sustainability and } \\
\text { macroeconomic stabilization } \\
\text { takes into account cyclical } \\
\text { macroeconomic shocks. }\end{array}$ & $\begin{array}{l}\text { Significant impact on debt } \\
\text { sustainability and } \\
\text { macroeconomic stabilization, } \\
\text { which can be adjusted due to } \\
\text { "discretionary valves" (escape } \\
\text { clause) }\end{array}$ & $\begin{array}{l}\text { The impact on debt sustainabil- } \\
\text { ity and macroeconomic stabili- } \\
\text { zation is insignificant, except } \\
\text { for countries with a certain or- } \\
\text { der of use of raw materials. }\end{array}$ \\
\hline
\end{tabular}

Figure 3. The impact of fiscal (debt) rules on the procyclical nature of fiscal policy and debt sustainability

Source: compiled by authors.

Thus, considering each rule separately, the most effective from the point of view of implementing countercyclical fiscal policy is the application of a modified rule of balanced budget on the basis of structural (adjusted for a cyclic component, calculated on the basis of "output gap" between actual and potential GDP) or cyclical balance (balance implementation during a certain phase of the business cycle). Often such rules are called "second generation" rules, which are of a bilateral nature: demonstrating the restrictive nature of fiscal policy in the stages of economic recovery and expansive at the stages of economic recession. The establishment of structural or cyclic targeting in balancing the budget is quite common in different countries of the world, which implement a balanced policy of debt sustainability management by minimizing gaps between budget revenues and expenditures and leveling the possibilities for the emergence of public debt. According to the IMF fiscal rules database, 22 countries belong to the macroeconomic stabilization countries: Australia, Chile, Colombia, Croatia, Denmark, Estonia, Finland, Germany, Italy, Latvia, Mongolia, the Netherlands, Norway, Panama, Peru, Romania, Serbia, Slovakia, Spain, Sweden, Switzerland and the United Kingdom. In general, the priority of applying the rule of budget balancing "through the cycle" and its combination with the debt rule and the expenditure rule is higher in developed countries, focused on the integrated use of fiscal regulation potential, than in developing countries. In these countries the introduction of the rule of expenditure or income encounters poor institutional capacity of governments but not the reasonableness of their policies, and the key rule remains debt.

World experience shows that the positive effect on debt sustainability and the countercyclical potential of fiscal policy of the state has a combination of debt rules and expenditure rules, and debt rules and budget balancing rules regarding the cycle. 
The relevance of inmplementation of these two rules in Ukraine, the formation of budgetary aggregates of which stands out as a counterweight to other countries in a significant procyclical manner (Figure 4) is undoubtful. Debt and fiscal policies in the conditions of inactivity of automatic stabilizers and manual control increased cyclical fluctuations, both at the stage of economic revival until 2008, and in the post-crisis period.

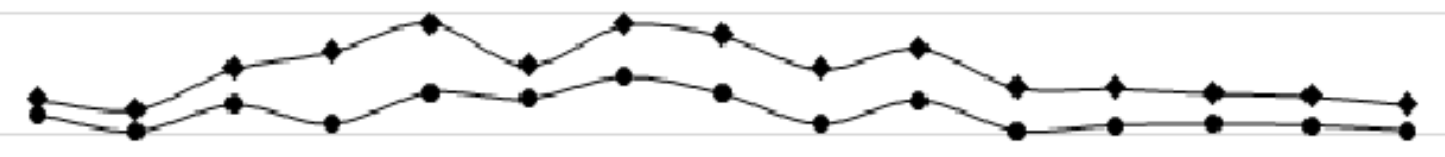

Consolidated revenues of the government, $\%$ of GDP - Consolidated expenditures of the govemment, $\%$ of GDP

Figure 4. Dynamics of incomes and expenditures of the government of Ukraine in 2006-2020, \% of GDP Source: compiled by authors [1].

Against the background of the US, EU and other developed countries (Figure 5), the dynamics of revenues and expenditures of which are generalized and predicted by the IMF, Ukraine has a high degree of procyclicality of these budget aggregates. These figures clearly show the desire of developed countries to fiscal consolidation in the long run with the assumption of low deficit values.

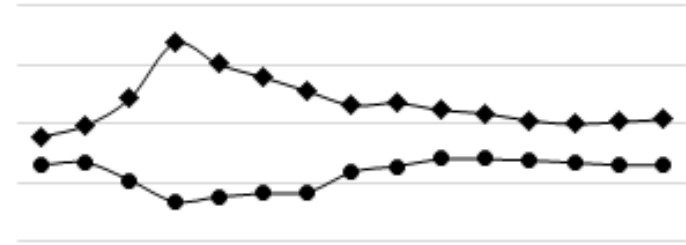

- Consolidated revenues of the government, $\%$ of GDP

- Consolidated expenditures of the govemment, $\%$ of GDP

USA

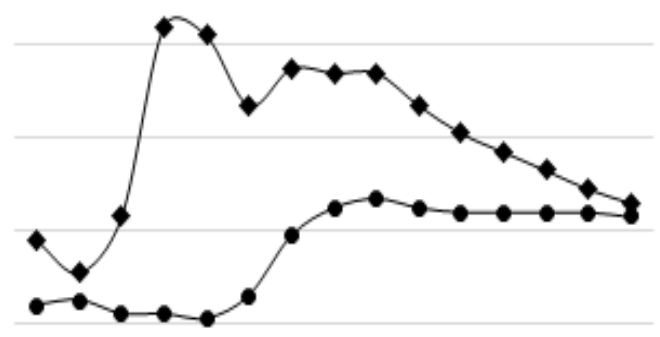

$\rightarrow-$ Consolidated revenues of the government, $\%$ of GDP

- Consolidated expenditures of the govemment, $\%$ of GDP

EU

Figure 5. Dynamics of revenues and expenditures of the state budget in the USA and the EU in 2006-2020, \% of GDP Source: compiled by authors [1].

At the same time, even in the crisis periods of 2008-2010, accompanied by a significant excess of expenditures over income, there were no signs of cyclicality in these countries. Moreover, middle-income countries and emerging markets, although they have a greater deficit (Figure 6) than developed countries, however, do not show expressed signs of cyclicality inherent in Ukraine. 


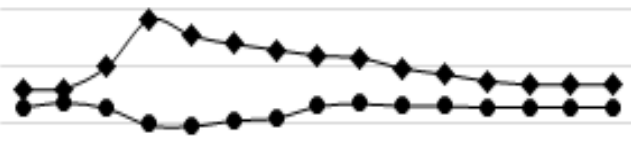

- Consolidated revenues of the government, $\%$ of GDP

- Consolidated expenditures of the govemment, $\%$ of GDP

Developed countries

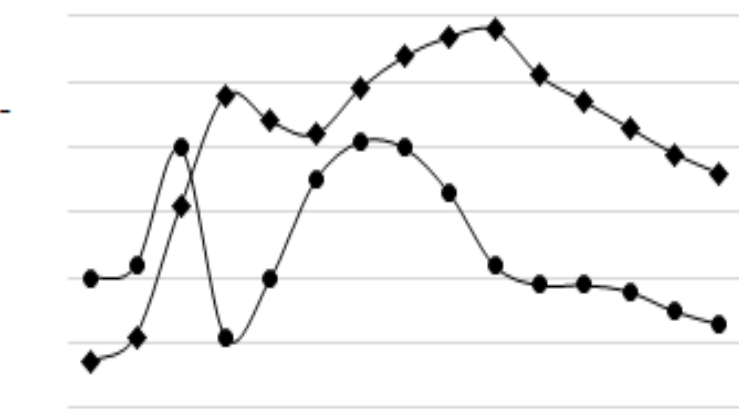

Consolidated revenues of the government, $\%$ of GDP

Consolidated expenditures of the govemment, $\%$ of GDP

Countries with middle-income and emerging markets

Figure 6. Dynamics of incomes and expenditures of the state budget of the countries of the world in 2006-2020,\% of GDP, average indicators

Source: compiled by authors [1].

The necessity of applying special countercyclic fixation rules is indicated by R. Tsytsyk. The author does not concretize and substantiate his proposals in detail. The work of foreign authors is an indirect proof of the need to take into account the influence of public debt on the cyclical nature of economic processes. M. Kumar proved that an increase in sovereign debt by $10 \%$ of GDP leads to a $0.2 \%$ drop in potential GDP growth, and if public debt exceeds a certain limit, economic growth rates slow down significantly.

To such conclusions also came C. Reinhart, K. Rogoff.

Among the key requirements to the mechanism of fiscal rules as a basis for managing debt sustainability of Ukraine, considering the analysis of the world and domestic experience of its functioning, can be called:

$>$ to ensure maximum transparency of use through monitoring and audit effectiveness;

$>$ to have a permanent basis for use, considering the need to trust economic agents, society;

$>$ to be flexible in terms of fiscal regulation during the business cycle;

$>$ to be suitable for use not only at the level of the state budget to regulate the government debt, but also be used at the level of local budgets as the basis for fiscal consolidation and regulation of municipal debt on a "bottom-up" basis;

$>$ consider debt indicators (for debt rules) in the most complete way: including the debt of state trust funds, national monopoly companies (Naftogaz of Ukraine, Ukrzaliznytsia) and municipal entities;

$>$ to have a built-in mechanism of accountability for their compliance, in particular separate penalties and preventive measures for the government (freezing wages, expressing mistrust, adopting no-deficit budget, a detailed plan for debt reduction);

$>$ to be monitored by the National Financial Agency of Ukraine for timely identification of deviations from the targeted budget and debt targets;

$>$ to meet the requirements of the fiscal rules established in the EU (the Maastricht Criteria for Convergence, the Stability and Development Pact, Sixpack and the Stability, Coordination and Management Agreement), considering the obligations of European integration.

In particular, the authors consider the combination of a number of fiscal (debt) rules of the "golden" rule with the debt rule of limiting the level of the debt quota in GDP and the structural rule of the government to be applied in Ukraine, taking into account the need for a comprehensive solution to the problems of the debt sustainability management system of deficit to GDP (Table 2). 
Table 3. Proposed medium-term and long-term guidance in the implementation of the mechanism of fiscal (debt) rules in Ukraine

\begin{tabular}{|c|c|c|c|c|c|}
\hline Guidance & Event type & Essence & \multicolumn{2}{|c|}{ Rules } & Targets \\
\hline \multirow{8}{*}{ Medium-term } & \multirow{3}{*}{$\begin{array}{l}\text { Introduction of } \\
\text { fiscal rules }\end{array}$} & \multirow{3}{*}{$\begin{array}{l}\text { Introduction at all levels of } \\
\text { general government sector, } \\
\text { including state off-budget } \\
\text { funds, state-owned } \\
\text { companies and banks. }\end{array}$} & \multicolumn{2}{|c|}{$\begin{array}{l}\text { Rules of debt (debt } \\
\text { brake). }\end{array}$} & $\begin{array}{l}\text { Strict restriction of the debt quota } \\
\text { at the level of } 60 \% \text { of GDP with a } \\
\text { gradual decrease to } 45 \% \text { of GDP. }\end{array}$ \\
\hline & & & \multirow{2}{*}{\multicolumn{2}{|c|}{$\begin{array}{l}\text { Rules of the } \\
\text { balanced budget on } \\
\text { the basis of the } \\
\text { structural balance } \\
\text { "Golden" rule of } \\
\text { financing } \\
\text { expenditures. }\end{array}$}} & $\begin{array}{l}\text { Achievements of the medium-term } \\
\text { budget target at the deficit level of } \\
1 \% \text { of GDP with a gradual } \\
\text { decrease to } 0.5 \% \text { of GDP }\end{array}$ \\
\hline & & & & & $\begin{array}{l}\text { Directions of attracted resources to } \\
\text { finance exclusively investment- } \\
\text { innovative costs, infrastructure } \\
\text { projects, rather than current } \\
\text { budget expenditures. }\end{array}$ \\
\hline & \multirow{3}{*}{$\begin{array}{l}\text { Measures } \\
\text { ensuring the } \\
\text { compliance } \\
\text { with fiscal } \\
\text { rules. }\end{array}$} & \multicolumn{4}{|c|}{$\begin{array}{l}\text { Development and implementation of a system of indicative and process monitoring of } \\
\text { compliance with the debt targets of fiscal rules. }\end{array}$} \\
\hline & & \multicolumn{4}{|c|}{$\begin{array}{l}\text { Development and implementation of a system for forecasting and monitoring the stages of } \\
\text { business cycle, identifying and preventing shocks and macroeconomic vulnerabilities in ad- } \\
\text { vance to accurately determination of boundaries of budget balancing and the allocation of } \\
\text { the cyclical component of budgetary targets. }\end{array}$} \\
\hline & & \multicolumn{4}{|c|}{$\begin{array}{l}\text { Creation of integrated system of regulatory, legal, organizational and communication } \\
\text { support for the introduction of a fiscal policy model based on fiscal (debt) rules and } \\
\text { updating the debt sustainability management system on fundamentally new principles. }\end{array}$} \\
\hline & & \multicolumn{4}{|c|}{$\begin{array}{l}\text { Limitations of cases and situations of rules violation (attraction of debt financing for } \\
\text { elimination of the consequences of natural disasters and catastrophes of national scale) and } \\
\text { predicting clear accountability and transparency of government structures responsible for } \\
\text { implementing fiscal policy, debt sustainability management (Ministry of Finance of } \\
\text { Ukraine) }\end{array}$} \\
\hline & & \multicolumn{4}{|c|}{$\begin{array}{l}\text { Introduction of comprehensive supervision, control and audit of the effectiveness of fiscal } \\
\text { policy implementation and debt sustainability management based on fiscal rules }\end{array}$} \\
\hline \multirow{4}{*}{ Long-term } & \multirow{2}{*}{$\begin{array}{l}\text { Introduction of } \\
\text { fiscal rules }\end{array}$} & \multirow[t]{2}{*}{$\begin{array}{l}\text { Introduction at all levels of } \\
\text { general government sector, } \\
\text { including state off-budget } \\
\text { funds, state-owned } \\
\text { companies and banks. }\end{array}$} & $\begin{array}{l}\text { Rules of } \\
\text { debt. }\end{array}$ & $\begin{array}{l}\text { Limita } \\
\text { levels } \\
\text { siderin } \\
\text { conjun } \\
\text { using }\end{array}$ & $\begin{array}{l}\text { is of expenditures in budgets of all } \\
\text { managers of budgetary funds con- } \\
\text { he state of macroeconomic } \\
\text { re and the stage of business cycle } \\
\text { retionary valves. }\end{array}$ \\
\hline & & & $\begin{array}{l}\text { Rules of } \\
\text { income. }\end{array}$ & $\begin{array}{l}\text { Directi } \\
\text { extraor } \\
\text { the sal } \\
\text { state st } \\
\text { the dir }\end{array}$ & $\begin{array}{l}\text { Dart of the excess cyclical revenues, } \\
\text { ary incomes, incomes received from } \\
\text { non-renewable minerals to a special } \\
\text { ization fund with strict regulation of } \\
\text { ons of their expenditures. }\end{array}$ \\
\hline & \multirow[t]{2}{*}{$\begin{array}{l}\text { Measures } \\
\text { ensuring the } \\
\text { compliance } \\
\text { with fiscal } \\
\text { rules. }\end{array}$} & \multicolumn{4}{|c|}{$\begin{array}{l}\text { Increasing the role of built-in automatic stabilizers (reduction of tax benefits, introduction of } \\
\text { progressive taxation systems, transparency in the formation and use of the revenue side of } \\
\text { the budget with a view to reducing the "manual" influence on budget implementation on a } \\
\text { deficit basis). }\end{array}$} \\
\hline & & \multicolumn{4}{|c|}{$\begin{array}{l}\text { Improving the effectiveness of the debt management system based on the prolongation of } \\
\text { debt obligations, targeting internal resources, improving the institutional quality of } \\
\text { management. }\end{array}$} \\
\hline
\end{tabular}

The rules of expenditures and income rules may be premature given the poor level of budgetary and debt discipline in Ukraine. In our opinion, their implementation should be postponed to the full implementation of already mentioned rules and they are differentiated in Table above according to the time guidelines for their implementation. Thus, the priority rule for implementation in the medium term (1-3 years) is the debt rule, the rule of structural balance of the budget and the "golden rule". In the long-term period (3-5 years) rules of income and expenditures are more appropriate for application and compliance.

The proposed rules are accompanied by separate accompanying measures for their implementation, which are in fact the directions for the development of the organizational and economic support of the fiscal policy model based on fiscal rules.

The introduction of a coherent system of fiscal rules and related activities in different time horizons will make it possible to regulate the debt management system of Ukraine in a comprehensive and flexible manner, develop a detailed scenario of actions regulating fiscal policy, and level out the impact of macroeconomic shocks and cyclical fluctuations on the debt sphere. 


\section{Conclusions}

Thus, considering the world practice of resolving sovereign debt crises, the changes in existing fiscal models towards the introduction of fiscal rules become widespread in various countries around the world. By differentiating fiscal rules with debt rules, balancing the budget, income and expenses, it is necessary to note the tendency towards their integrated application to achieve medium-term budgetary targets and emphasize the exceptional importance of rules for balancing the budget on a cyclical basis or since a structural balance. These rules should have a significant procyclical effect, which makes it expedient to implement them in Ukraine along with the debt rule in the medium term. The basis for the development of the mechanism for the application of fiscal (debt) rules is the author's scientific and methodical approach, which makes it possible to level out the procyclicality of fiscal policy, maintain at a given level the values of debt targets and ensure the implementation of guidance for medium-term and long-term debt sustainability.

\section{References}

1. Fiscal Monitor: Now Is the Time Fiscal Policies for Sustainable Growth, April 2015, IMF. Retrieved from http://www.imf.org/external/pubs/ft/fm/2015/01/fmindex.htm.

2. Koziuk, V. (2008). Borhova polityka v systemi hlobalnykh makrofinansovykh protsesiv [Debt policy in the system of global macrofinance processes]. Svit finansiv, 1, 29- 40.

3. Savchenko, T.H. (2015). Dylema dyskretnosti ta pravyla u fiskalnii i monetarnii politytsi [The discretionary dilemma and rules in fiscal and monetary policy]. Visnyk Zhytomyrskoho derzhavnoho tekhnolohichnoho universytetu. Seriia: Ekonomichni nauky, 3, 170-176.

4. Schaechter, A., Kinda, T., Budina, N., Weber, A. (2012). Fiscal Rules in Response to the Crisis-Toward the 'Next-Generation' Rules: A New Dataset. IMF, 49 p.

5. Skrypnyk, D.V. (2016). Biudzhetnye pravyla, effektivnost' pravytelstva i ekonomicheskyi rost: nauchnyi doklad [Budgetary rules, government effectiveness and economic growth: a scientific report]. M.: Institut ekonomiki RAN, $46 \mathrm{p}$.

6. Solohub, I. (2015). Fiskalni pravyla [Fiscal rules]. Retrieved from http://www.slideshare.net/KyivSchoolofEconomics/ss-48930847.

7. Tsytsyk, R.V. (2014). Napriamy pidvyshchennia fiskalnoi stiikosti v Ukraini [Directions of increasing fiscal sustainability in Ukraine]. Naukovi pratsi NDFI, 3, 89-103.

8. Tsytsyk, R.V. (2015). Fiskalna stiikist ta umovy yii zabezpechennia v Ukraini [Fiscal sustainability and the conditions for its provision in Ukraine]. Ph.D. Thesis; Derzh. navch.-nauk. ustanova «Akad. finans. upr.». Kyiv, $24 \mathrm{p}$. 